\title{
ECONOMIC ANALYSIS OF FRESHWATER AQUACULTURE PRODUCTION: A COMPARATIVE ANALYSIS OF DIFFERENT PRODUCTION SYSTEMS
}

\author{
H. Kumar, Research Scholar \\ R. Singh, Professor \\ Department of Agricultural Economics \\ Institute of Agricultural Science, Varanasi, India \\ E-mail: hradaykumarbhu@gmail.com
}

\begin{abstract}
India produced 8.29 million tonnes of fish in $2010-2011$. The industry contributes nearly INR 200 trillion to the national economy, forming 1.4 percent of national gross domestic product (GDP) and 5.4 percent of Agricultural GDP. At present, almost 84 percent of the total inland fish production, in the country is contributed by freshwater aquaculture amounting to 3.9 million tonnes in 2008-09. Further, the potential of the vast freshwater resources covering 6.7 million hectare is yet to be fully realized. The freshwater aquaculture which began as small scale activity of stocking ponds with fish seed collected from riverine sources during early fifties in rural Bengal has now transformed into a major economic activity in almost all states. There is a further need to make the sector more vibrant so as to achieve the predicted target of $15 \mathrm{~kg}$ per capita fish availability in the country by 2030 .
\end{abstract}

\section{KEYWORDS}

Ponds; Fish ponds; Production functions; Aquaculture; Fish; Disease control; Fixed costs.

Capture fishery in the country being almost stagnant since last three decades, freshwater sector has been shouldering the major responsibility to meet the increased demand for fish. Now, quality fish protein supply, nutrient security of consumers, livelihood security of producers and traders are all linked with the growth and development of this sector. This study was confined in Eastern Uttar Pradesh which comprises 15 districts. Maharajganj district being the highest fish producing district was selected purposively. A list of all 12 blocks was prepared on the basis of fish production. Two blocks having highest fish production viz. Partawal, Mithaura and two blocks with lowest fish production viz. Bridzemanganj, Pharenda, were selected purposively. A list of villages and fisher's along with fish production was prepared and three were categorized in to viz. Private fish ponds, community fish ponds and leased fish ponds. Total of 200, fishers of four blocks were selected for the study. Primary data were collected with the worked pretesting scheduled.

\section{METHODOLOGY}

Analytical framework. To workout the cost and returns structure, the tabular analysis was employed. Thecosts, returns and profit in Maharajganj district (MD) and BHU ponds aquaculture production systems computed on per hectare basis were compared and contrasted .the cost of human labour was estimated in terms of 8 man hours. The costs machine labourboth owned and hired were calculated at the prevailing rates. The costs of ponds produced fish seeds and farm yard manure (FYM) were imputed at the market price in the village including the cost of transportation and other incidental charges, if any. The cost of purchased fingerlings (fish seed) fertilizers, lime, feed, disease control chemicals were calculated based on the actual expenditure incurred the amount of fixed by the government for irrigation and land revenue was considered for computation of this cost. The rental value of pond was imputed based on the prevailing rents in the study area. The short term and long term bank lending rates were used to work out the interest on working and fixed capital respectively. The depreciation was calculated by the strait line method.The charges on account of minor repairs of implements and machinery during the year were added to the depreciation charges .the interest on fixed capital and depreciation were apportioned on the basis of area of land under each crop grown during the year. The gross returns were computed were multiplying the quantity of product with respective prices received. 
The resource use efficiency was assessed by comparing marginal value product (MVP) with factor cost of the resources the marginal product (MP) was estimated from the parameters of Cobb-Douglas production function and the geometric mean level of output and input. Decomposition analysis was employed to figure out the sources contributing to the yield differences between the systems. Dummy variable technique was employed to know the nature of technological change between Maharajganj fisher's pond and BHU pond production systems of aquaculture. The output decomposition model as developed by Bisaliah (1977) was used for investigating the contribution of various constituent sources to the productivity difference between the BHU fish ponds and the Maharajganj fisher's ponds production systems. For any two production functions, the total change in the Productivity could be brought out by shifts in the production parameters that defined the production function itself and by the changes in the input use levels. Therefore, the production functions were considered as the convenient econometric tools for decomposing the productivity difference between the BHU fish ponds and the maharajganj fish ponds production systems.. Two separate production functions, one for BHU fish ponds production and another for maharajganj fish production systems were fitted as follows. In logarithm form, Cobb-Douglas production function for $\mathrm{BHU}$ fish ponds is:

$$
\ln Y_{B}=\ln a_{B}+b_{B 1} \ln X_{B 1}+b_{B 2} \ln X_{B 2}+b_{B 3} \ln X_{B 3}+b_{B 4} \ln X_{B 4}+b_{B 5} \ln X_{B 5} b_{B 6} \ln X_{B 6}+U_{B} \ldots . .(1)
$$

Logarithm form of Cobb-Douglas production function for maharajganj fish ponds is:

$$
\ln Y_{M}=\ln a_{M}+b_{M 1} \ln X_{M 1}+b_{M 2} \ln X_{M 2}+b_{M 3} \ln X_{M 3}+b_{M 4} \ln X_{M 4}+b_{M 5} \ln X_{M 5}+b_{M 6} \ln X_{M 6}+U_{M} \ldots
$$

Taking differences between (1) and (2) and adding some terms and subtracting the same terms.

$$
\begin{gathered}
\ln Y_{B}-\ln Y_{M}=\left(\ln a_{B}-\ln a_{M}\right)+\left(b_{B} \ln X_{B 1}-b_{M 1} \ln X_{M 1}+b_{B 1} \ln X_{B 1}-b_{B 1} \ln X_{B 1}\right)+\left(b_{B 2} \ln X_{B 2}-b_{M 2} \ln X_{M 2}+\right. \\
\left.b_{B 2} \ln X_{B 2}-b_{B 2} \ln X_{B 2}\right)+\left(b_{B 3} \ln X_{B 3}-b_{M 3} \ln X_{M 3}+b_{B 3} \ln X_{B 3}-b_{B 3} \ln X_{B 3}\right)+\left(b_{B 4} \ln X_{B 4}-b_{M 4} \ln X_{M 4}+\right. \\
\left.b_{B 4} \ln X_{B 4}-b_{B 4} \ln X_{B 4}\right)+\left(b_{B} \ln X_{B 5}-b_{M 5} \ln X_{M 5}+b_{B 5} \ln X_{B 5}-b_{B 5} \ln X_{B 5}\right)+\left(b_{B 6} \ln X_{B 6}-b_{M 6} \ln X_{M 6}+\right. \\
\left.b_{B 6} \ln X_{B 6}-b_{B 6} \ln X_{B 6}\right)+\left(U_{B}-U_{M}\right) \ldots(3)
\end{gathered}
$$

By using logarithm rule equation (13) becomes:

$\ln \left(\mathrm{Y}_{\mathrm{B}} / \mathrm{Y}_{\mathrm{M}}\right)=\left\{\ln \left[\mathrm{a}_{\mathrm{B}} / \mathrm{a}_{\mathrm{M}}\right)\right\}+\left\{\left(\mathrm{b}_{\mathrm{B} 1}-\mathrm{b}_{\mathrm{M} 1}\right) \ln \mathrm{X}_{\mathrm{B} 1}+\left(\mathrm{b}_{\mathrm{B} 2}-\mathrm{b}_{\mathrm{M} 2}\right) \ln \mathrm{X}_{\mathrm{B} 2}+\left(\mathrm{b}_{\mathrm{B} 3}-\mathrm{b}_{\mathrm{M} 3}\right) \ln \mathrm{X}_{\mathrm{B} 3}+\left(\mathrm{b}_{\mathrm{B} 4}-\right.\right.$ $\left.\left.b_{M 4}\right) \ln X_{B 4}+\left(b_{B 5}-b_{M 5}\right) \ln X_{B 5}+\left(b_{B 6}-b_{M 6}\right) \ln X_{B 6}\right\}+\left\{b_{B 1} \ln \left(X_{B 1} / X_{M 1}\right)+b_{B 2} \ln \left(X_{B 2} / X_{M 2}\right)+b_{B 3} \ln \right.$

$\left(X_{B 3} / X_{M 3}\right)+b_{B 4} \ln \left(X_{B 4} / X_{M 4}\right)+b_{B 5} \ln \left(X_{B 5} / X_{M 5}\right)+b_{B 6} \ln \left(X_{B 6} / X_{M 6}\right)+\left[\left(U_{B}-U_{M}\right)\right] \ldots \ldots(4)$,

where:

$\mathrm{Y}_{\mathrm{B}}=$ output in quintal/ha (BHU); $\mathrm{Y}_{\mathrm{M}}=$ output in quintal/ha (MGD);

$\mathrm{X}_{1}=$ Seeds in Rs/ ha; $\mathrm{X}_{2}=$ feed in Rs/ ha;

$\mathrm{X}_{3}=$ Fertilizer in Rs/ ha; $\mathrm{X}_{4}=$ Manure in Rs/ ha;

$\mathrm{X}_{5}=$ lime in $\mathrm{Rs} / \mathrm{ha} ; \mathrm{X}_{6}=$ Irrigation charges Rs/ha;

In = natural logarithms; $u=$ Error term.

This is the decomposition model for decomposing the productivity difference between the BHU fishponds and Maharajganj fish ponds production system. This equation involves decomposing the logarithm of ratio of per hectare productivity of the BHU fishponds and Maharajganj fish ponds production systems (LHS). This is approximately a measure of percentage change in per hectare output between the BHU fishponds and Maharajganj fish ponds production system. The summation of first and the second terms on the right hand side of the decomposition model together represented the productivity difference between the $\mathrm{BHU}$ fishponds and Maharajganj fish ponds production systems attributable to the difference in the cultural practices. The third term provided the productivity difference 
between the BHU fishponds and Maharajganj fish ponds production systems attributable to the differences in the input use.

Dummy variable Technique. To examine whether the parameters of the production function of $\mathrm{BHU}$ ponds production systems were different from those of the Maharajganj fisher's ponds production systems. Dummy variable technique was used. The following dummy variable model introducing intercept and slope dummy was specified:

$\operatorname{Ln} Q=\ln +b_{0}+b_{1} \ln X_{1}+b_{2} \ln X_{2}+b_{3} \ln X_{3} b_{4} \ln X_{4}+b_{5} \ln X_{5}+b_{6} \ln X_{6}+c D+d_{1}\left(D \ln X_{1}\right)+d_{2}$ $\left(D \ln X_{2}\right)+d_{3}\left(D \ln X_{3}\right)+d_{4}\left(D \ln X_{4}\right)+d_{5}\left(D \ln X_{5}\right)+d_{6}\left(D \ln X_{6}\right)+\ln u$

Dummy values: $D=1$ If it is $B H U$ production systems. $D=0$ if it isMaharajganj fisher's pondsproduction systems.

\section{RESULTS AND DISCUSSION}

Costs and returns in md fishers ponds and bhu fish ponds production system. Cost of aquaculture production system includes both operational as well as fixed cost .operational cost includes the cost of fish seed, human labour, machine labour, manures and fertilizers, irrigation charges insecticide, lime, feed and interest on working capital .fixed cost includes the rental value of owned pond, rent paid for leased in pond, land revenue, rental value of owned pond, rent paid for leased in community fish pond, rent paid for leased in private fish pond, depreciation charges, and interest on fixed capital.

Table 1. Comparison of Costs and returns of aquaculture of Maharajganj district fishers ponds and BHU fish ponds (Rs/ha)

\begin{tabular}{|c|c|c|}
\hline Item & Maharajganj & BHU fish ponds \\
\hline \multicolumn{3}{|c|}{ Operational costs } \\
\hline Seed & $2270.57(3.10)$ & $1500.00(1.61)$ \\
\hline Feed & $3573.57(4.88)$ & $4750.00(5.09)$ \\
\hline Irrigation & $3352.80(4.58)$ & $5000.00(5.36)$ \\
\hline Manure & $2223.00(3.04)$ & $4000.00(4.29)$ \\
\hline Lime & $927.07(1.26)$ & $1600.00(1.71)$ \\
\hline Fertilizers & $835.41(1.14)$ & $3620.00(3.88)$ \\
\hline Disease control & $447.43(0.61)$ & $850.00(0.91)$ \\
\hline Human labour & $7387.72(10.10)$ & $16300.00(17.49)$ \\
\hline Machine labour & $514.01(0.70)$ & $1200.00(1.28)$ \\
\hline Miscellaneous expences & $242.58(0.33)$ & $500.00(0.53)$ \\
\hline Interest on working capital & $2721.76(3.72)$ & $4915.00(5.27)$ \\
\hline Sub Total & $24495.97(33.50)$ & $44235.00(47.48)$ \\
\hline Fixed costs & $41974.25(57.40)$ & $40446.54(43.42)$ \\
\hline $10 \%$ of Managerial of sub total & $6647.01(9.09)$ & $8468.15(9.09)$ \\
\hline Grand Total & $73117.23(100.00)$ & $93149.69(100.00)$ \\
\hline Production (Kg/ha) & 2191.18 & 3000.00 \\
\hline Gross income & 168900.76 & 240000.00 \\
\hline Net income & 95783.53 & 146850.31 \\
\hline
\end{tabular}

Note: figures in the parentheses indicate percentages to total

Cost of aquaculture production systems of B.H.U fish pond per hectare is given table (1) total cost per hectare Rs. (93149.69) was more when compared to that in Maharajganj fisher's pondsproduction systems (Rs. 73117.23). The share of Maximum difference was observed in the cost of human labour. on an average sample fish farms incurred Rs.16300 was incurred towards human labour in BHU fish farm production system while only 7387.12 was incurred towards human labour in Maharajganj fish ponds production system. irrigation chargeswas the next important item of expenditure in both the systems of aquaculture production which worked out to be Rs.3352.80. (4.58 percent) and Rs.5000.00 (5.36 percent) of total cost, respectively in Maharajganj fisher's pondsproduction systemsand BHU ponds 
production systems. Expenditure incurred on seed per hectare Rs.2270.57 (3.10 percent) was more in the case of Maharajganj fisher's ponds production systems. compared to that BHU production systems Rs.1500 per hectare, (1.61 percent) of total cost. The amount spent on FYM, lime fertilizers, feed, machine labuor, expenditure of disease control in BHU production systems was more when compared to that MGD production systems table (1). Operational cost per hectare was higher Rs.44235.00 in BHU production systems when compared to that in MGD production systems Rs. 24495.97. Fixed cost Rs.41974.25 (57.40 percent) in MGD production systems was more when compared to that in BHU production systems Rs.40446.54 (43.42 percent).

Gross income obtained per hectare was more in BHU fish farm than that of Maharajganj fish ponds. It was Rs.240000 in BHU fish ponds and Rs.168900.76 in Maharajganj fish ponds per hectare. But net income was more in BHU fish farm.it was Rs.146850.31 in BHU fish ponds and Rs.95783.53 in Maharajganj fish ponds per hectare. This was due to the comparatively lower expenditure on production of Maharajganj fish ponds production systems.

Decomposition of factors contribution to productivity difference between BHU and MD aquaculture production systems. In order to test the difference in the structural production relationship in the parameters defining the production functions for the two systems, the log linear production function with both intercept and slope dummies was estimated.

This result facilitated of the hypothesis that production parameters defining the BHU fish production systems and MD fisher's pondsaquaculture production systems are same. The positive estimates of intercept and slope dummy coefficients for all resources implied that the output in BHU production systems is significantly higher than that in the MD fisher's pondsaquaculture production systems for a given level of resources .they also implied larger regression coefficients of production with respect to each input under BHU aquaculture production systems compared to MD fisher's pondsaquaculture production systems. The result as such offered the required justification for decomposing the factor contributing to productivity difference between BHU ponds aquaculture production systems and MD fisher's pondsaquaculture production systems.

For decomposing the productivity difference between BHU production systems and MD fisher's pondsaquaculture production systems, the parameters of the per hectare production function and the mean level of input use for the two systems were essential. Hence, the production functions for BHU production systems and MD fisher's pondsaquaculture production systems were also estimated separately. The estimates provided in table .As much as 80.10 percent and 69.10 percent of variation in aquaculture output ,respectively, in MD systems and BHU ponds systems was explained by the independent variables. The constant term (intercept) in the case of BHU systems was higher than that for the MD fisher's pondsaquaculture production systems. This virtually signified that there was an upward shift in production function due to technological change associated with BHU ponds. The production regression coefficient of fingerlings (fish seed), feed, manure, lime, water recharges, fertilizers, disease control (chemical) ,laboure, Were positive and significant in MD fisher's pondsaquaculture production systems and BHU ponds production systems regression coefficient of feed, lime ,fertilizers, disease control (chemical) and human laboure were positive and significant, seed manure, water recharges were negative regression coefficient. The output regression coefficients seed water recharges, manure, disease control items in case of MD fisher's pondsaquaculture production systems were relatively greater as compared to those for BHU ponds production systems. The output regression coefficients feed, fertilizers, laboure and lime items in case of BHU ponds production systems were relatively greater as compared to those for MD fisher's pondsaquaculture production systems. The aquaculture output in MD fisher's pondsaquaculture production systems would increase by 0.462 percent and 0.020 percent for every one percent increase in the use of seed and manure.in case of BHU pondssystems, the aquaculture output would increase by 0.147 percent, 0.056 percent, 0.569 percent and 0.227 percent for every one percent increase in the use of feed lime, fertilizers and human laboure. Thus, the major contribution to output in BHU aquaculture production systems came from feed lime and fertilizers. 
Table 2. Estimated production functions with intercept and slop dummies

\begin{tabular}{|c|c|c|c|c|c|c|c|}
\hline \multirow[b]{2}{*}{$\begin{array}{l}\text { S. } \\
\text { No. }\end{array}$} & \multirow[b]{2}{*}{ Particulars } & \multicolumn{2}{|c|}{ Pooled } & \multicolumn{2}{|c|}{ MD fisher's ponds } & \multicolumn{2}{|c|}{ BHU ponds } \\
\hline & & $\begin{array}{l}\text { Regression } \\
\text { coefficient }\end{array}$ & $\begin{array}{l}\text { Standard } \\
\text { error }\end{array}$ & $\begin{array}{l}\text { Regression } \\
\text { coefficient }\end{array}$ & $\begin{array}{l}\text { Standard } \\
\text { error }\end{array}$ & $\begin{array}{l}\text { Regression } \\
\text { coefficient }\end{array}$ & $\begin{array}{l}\text { Standard } \\
\text { error }\end{array}$ \\
\hline 1. & Intercept & $4.384^{\star \star}$ & 0.309 & $4.379^{\star \star}$ & 0.659 & $5.335^{\star \star}$ & 1.698 \\
\hline 2. & Seed (fingerlings) & $0.460^{\star \star \star}$ & 0.048 & $0.462^{\star \star}$ & 0.083 & -0.215 & 0.111 \\
\hline 3. & feed & $0.086^{\star \star}$ & 0.021 & $0.086^{\star \star}$ & 0.021 & 0.147 & 0.074 \\
\hline 4. & manure & 0.020 & 0.023 & 0.020 & 0.024 & -0.017 & 0.019 \\
\hline 5. & Water recharges & 0.034 & 0.019 & 0.034 & 0.027 & -0.081 & 0.068 \\
\hline 6. & lime & 0.006 & 0.023 & 0.006 & 0.020 & 0.056 & 0.147 \\
\hline 7. & fertilizers & $0.098^{\star \star}$ & 0.022 & $0.098^{\star \star}$ & 0.024 & $0.569^{*}$ & 0.266 \\
\hline 8. & Disease control(chemical) & 0.062 & 0.025 & 0.062 & 0.024 & 0.052 & 0.110 \\
\hline 9. & Human labour & $0.213^{\star \star}$ & 0.062 & $0.212^{\star *}$ & 0.065 & 0.227 & 0.115 \\
\hline & Intercept & 10.278 & 0.198 & & & & \\
\hline & (a)Seed (fingerlings) & 0.023 & 0.111 & & & & \\
\hline & (b)feed & 0.065 & 0.050 & & & & \\
\hline & (c)manure & 0.002 & 0.056 & & & & \\
\hline & (d) Water recharges & 0.013 & 0.045 & & & & \\
\hline & (e)lime & -0.101 & 0.055 & & & & \\
\hline & (f) fertilizers & -0.020 & 0.054 & & & & \\
\hline & $\begin{array}{l}\text { (g)Disease } \\
\text { control(chemical) }\end{array}$ & -0.041 & 0.058 & & & & \\
\hline & (h) Human labour & $0.114^{\star}$ & 0.109 & & & & \\
\hline 10. & $\begin{array}{l}\text { Coefficient of multiple } \\
\text { determination(R2) }\end{array}$ & 0.76 & & 0.801 & & 0.691 & \\
\hline 11. & $\begin{array}{l}\text { Adjusted Coefficient of } \\
\text { multipledetermination }(R 2)\end{array}$ & 0.75 & & 0.793 & & 0.466 & \\
\hline 12. & F value & 67.06 & & 95.783 & & 3.072 & \\
\hline
\end{tabular}

Note: Figures in parentheses are standard errors.

** Significant at $1 \%$ level and *Significant at $5 \%$ level, respectively.

Table 3. Decomposition of productivity difference between the BHU ponds production systems and the MD fisher's ponds production systems

\begin{tabular}{|c|c|c|}
\hline SI. No. & Sources of output differences & Percentage contribution \\
\hline l. & Total difference in output & 23.34 \\
\hline III. & Source of contribution & - \\
\hline 1. & Due to difference in Technology & 21.25 \\
\hline 2. & Due to difference in input use & - \\
\hline a) & Seed (fingerlings) & 8.44 \\
\hline b) & Feed & -0.83 \\
\hline c) & Manure & -0.07 \\
\hline d) & Water recharges & -0.29 \\
\hline e) & Lime & 0.04 \\
\hline f) & Fertilizers & -7.17 \\
\hline g) & Disease control(chemical) & 0.74 \\
\hline h) & Human labour & 1.90 \\
\hline IIII. & Estimated difference in output & 22.92 \\
\hline
\end{tabular}

Table 4. MVP to MFC ratios of resources in MD and BHU ponds aquaculture production systems

\begin{tabular}{|c|c|c|c|c|c|c|c|}
\hline \multirow{2}{*}{$\begin{array}{l}\text { Sl. } \\
\text { No. }\end{array}$} & \multirow{2}{*}{ Particulars } & \multicolumn{3}{|c|}{ MGD MD fisher's ponds } & \multicolumn{3}{|c|}{ BHU ponds } \\
\hline & & MVP & MFC & Ratio & MVP & MFC & Ratio \\
\hline 1. & Seed (fingerlings) $(\mathrm{Kg})$. & 30.73 & 117.72 & 0.26 & -32.86 & 100 & -0.32 \\
\hline 2. & Feed (Qt.) & 7.12 & 6.00 & 1.18 & 7.38 & 6.00 & 1.23 \\
\hline 3. & Manure (Tonnes) & 0.95 & 112.37 & 0.008 & -3.89 & 120 & -0.03 \\
\hline 4. & Lime $(\mathrm{Kg})$ & 1.31 & 8.50 & 0.15 & 0.15 & 6.50 & 0.023 \\
\hline 5. & Fertilizers $(\mathrm{Kg})$ & 32.02 & 12.00 & 2.66 & 39.88 & 12.00 & 3.32 \\
\hline 6. & Disease control (chemical)(Rs) & 41.71 & 295.17 & 0.14 & 17.18 & 80 & 0.21 \\
\hline 7. & Human labour (man days) & 4.60 & 100.00 & 0.046 & 3.2 & 158.65 & 0.02 \\
\hline
\end{tabular}


To analyse the scope for intensification of resources in both systems, the marginal value products (MVP) of resources are compared with the respective marginal factor cost (MFC). The MVP and MFC ratios for different resources for both the systems were furnished in Table 2. It is revealed from feed and fertilizer were underutilized as their ratio was more than one therefore it was conducted that profitability may be increased by offer more and feed and fertilizer on both ponds .manure was done utilized on BHU ponds as its reach was negative while there is great scope to improve the production by offer manure a fishers ponds. The decomposition analysis revealed that the per hectare production of MD fisher's ponds aquaculture production systemswas less than that in BHU ponds production systems of aquaculture 23.34 per cent (Table 3) and the estimated difference 22.92 per cent difference in the productivity of BHU ponds production systems and MD fisher's pondsaquaculture production systems. This implied that aquaculture output could be enhanced by nearly 23.00 Percent if the BHU production systems of aquaculture were adopted by all the fish growing fishers. The contribution of BHU ponds systems technology to the productivity difference between the production systems of aquaculture was estimated at 21.25 percent.

The contribution of differences in input levels to the productivity differences between the $\mathrm{BHU}$ systems and MD fisher's pondsaquaculture production systemswas meager and it was 23.34 per cent. Seed (8.44 percent), feed ( -0.83 percent), fertilizer ( -7.17 percent), manure $(-0.07$ percent), lime (0.04 percent) water recharges $(-0.29$ percent) expenditure of disease control ( 0.74 percent) and human laboure (1.90 percent) respectively. This implied that farmers growing in $\mathrm{BHU}$ production systems of aquaculture obtained higher output per hectare than that obtained by the fishers of MD fisher's pondsaquaculture production systemsby spending less on those inputs. Altogether, the total contribution of differences in the levels of input use to the productivity gap accounted for 23.34 per cent, indicating that the productivity on MD fisher's pondsaquaculture production systemscould be increased by about 22.92 per cent, if the per hectare input use levels on these ponds could be increased to the same level as on the MD fisher's pondsaquaculture production systems.

\section{CONCLUSION}

Gross income obtained per hectare was more in BHU fish farm than that of Maharajganj fish ponds. It was Rs.240000 in BHU fish ponds and Rs.168900.76 in Maharajganj fish ponds per hectare. But net income was more in BHU fish farm.it was Rs.146850.31 in BHU fish ponds and Rs.95783.53 in Maharajganj fish ponds per hectare. This was due to the comparatively lower expenditure on production of Maharajganj fish ponds production systems. The share of Maximum difference was observed in the cost of human labour. on an average sample fish farms incurred Rs.16300 was incurred towards human labour in BHU fish farm production system while only 7387.12 was incurred towards human labour in Maharajganj fish ponds production system.Total cost per hectare Rs.( 93149.69) was more when compared to that in MD fisher's pondsaquaculture production systems (Rs. 73117.23). Operational cost per hectare was higher Rs.44235.00 in BHU production systems when compared to that in MD fisher's pondsaquaculture production systemsRs. 24495.97. Fixed cost Rs.41974.25 (57.40 percent) in MD fisher's pondsaquaculture production systemswas more when compared to that in BHU ponds production systemsRs.40446.54 (43.42 percent).

The estimated production was significant with high $\mathrm{R}^{2}$ for both the $\mathrm{BHU}$ ponds production systems and MD fisher's pondsaquaculture production systems. The production regression coefficient of fingerlings (fishseeds), feed, manure, lime, water recharges, fertilizers, disease control (chemical) ,laboure, Were positive and significant in MD fisher's pondsaquaculture production systemsand BHU ponds production systems regression coefficient of feed, lime ,fertilizers, disease control (chemical) and human laboure were positive and significant ,seed manure, water recharges were negative regression coefficient.The technological change in aquaculture production systems has brought 21.25 percent productivity difference between the two production systems. The major component of this productivity difference was due to the difference in systems of production, which contributed to 23.34 percent. 


\section{REFRENCES}

[1] Annual report, Department of Animal Husbandry, Dairying \& Fisheries, Ministry of Agriculture Government of India New Delhi, 2011-12.

[2] Bisalaiah,S., decomposition analysis of output change under new production technology in wheat farming: Some implications to returns on investment. Indian Journal of Agricultural Economics, 32(3), pp 193-201, 1977.

[3] Balakrishna,A., Economics of Bt cotton in India Journal of Development and Agricultural Economics Vol. 4(5), pp. 119-124, 12 March, 2012.

[4] Basavaraja, H., Mahajanashetti, S.B.andSivanagaraju,P., Technological change in paddy production .A comparative Analysis of traditional and SRI method of cultivation. Indian journal of Agricultural Economics, vol.63 (4), pp 629-640, 2008.

[5] Hugar, L. B., and Patil, B. V., Productivity difference between bt and non bt cotton farms in Karnataka state, India-an Econometric evidence college of Agriculture,lingasugur road, Raichur, 584101, India, 2007.

[6] Maheswari ,R.,Ashok, K. R., and Prahadeeswaran , M.,Precision Farming Technology, Adoption Decisions and Productivity of Vegetables in Resource-Poor Environments, Agricultural Economics Research Review Vol. 21: pp 415-424, 2008.

[7] Sharma, A. and Nizamuddin., Fish production in rainfed area of Uttar Pradesh a regression approach,Journal of Interacademicia. 8(3): pp 441-446, 2004. 